\title{
Moniammatillisuus rikastaa asiantuntijan työtä
}

Mönkkönen, Kaarina, Kekoni, Taru \& Pehkonen, Aini (toim.) (2019) Moniammatillinen yhteistyö - Vaikuttava vuorovaikutus sosiaali- ja terveysalalla. Gaudeamus. 176 sivua.

TUTKIMUSPOHJAISELLE tiedolle moniammatillisuudesta on ollut tarvetta. Moniammatillinen yhteistyö avaa moniammatillisuuden käsitettä, kuvaa asiakkaan roolia moniammatillisella sosiaali- ja terveysalalla ja antaa näkökulmia moniammatillisen osaamisen kehittämiseen.

Kirjan toimittajat ovat sosiaalityön asiantuntijoita Itä-Suomen yliopistosta. Heidän lisäkseen 12 asiantuntijaa kuvaa muun muassa moniammatillisen työskentelyn muotoja, yhteistyötä ja vuorovaikutusta. Moniammatillista työtä esitellään varteenotettavana vaihtoehtona sosiaali- ja terveysalalla, jolla yhä useammin korostetaan monitoimijaisuutta, palveluiden sujuvuutta ja asiakkaan etua.

\section{MITÄ MONIAMMATILLISUUS ON?}

Kirjassa määritellään kattavasti moniammatillisuuden käsitettä: Verkostot ja viranomaiset toimivat yhdessä yhteisen tavoitteen tai tehtävän hyväksi. Ryhmän jäsenten välinen avoimuus, luottamus ja ymmärrys erilaisista arvoista, kulttuureista ja tietoperustoista edistää työskentelyä. Yhteistyö voi nivoutua johonkin asiaan tai toiminta voi päättyä, kun ongelma on ratkaistu. Moniammatillinen työ voi myös olla pitkäkestoista, kuten potilaan hoitoon tähtäävien ryhmien toiminta. Sosiaali- ja terveysalalla moniammatillinen työ on lisääntynyt palveluiden yhdistymiseen tähtäävän uudistuksen myötä, mikä on muuttanut monen alan ammattilaisten työtä ja työkulttuuria. Näin toimijat haastetaan reflektoimaan asiantuntijuutta.

Moniammatillista toimintaa edistää kirjoittajien mukaan neljä työyhteistyötaitoa: moniammatillisen osaamisen kehittäminen, paineensietokyky, asiallinen ja yhteishenkeä rakentava vuorovaikutus sekä ymmärrys omasta työroolista työyhteisössä. Johtamisella tuetaan erilaisten toimijoiden yhteistyötä, raja-aitojen ylityksiä ja jaettua vastuuta. Kirjassa on tuoreita näkökulmia ja käytännön vinkkejä yhteistyötaitojen ja uudenlaisen johtajuuden kehittämiseen.

Kirjoittajat tuovat esille, että yhteiskuntamme monimutkaisten haasteiden ratkaisemiseen tarvitaan kokonaisvaltaisia ajattelu- ja toimintatapoja, ja siinä moniammatillisuudesta on hyötyä. Se ei tarkoita oman ammatti-identiteetin hämärtymistä tai toimintatapojen yhtenäistämistä vaan ongelmien pohtimista ammattiryhmien omista näkökulmista yhdistellen asiantuntijoiden tietopohjia ja osaamista.

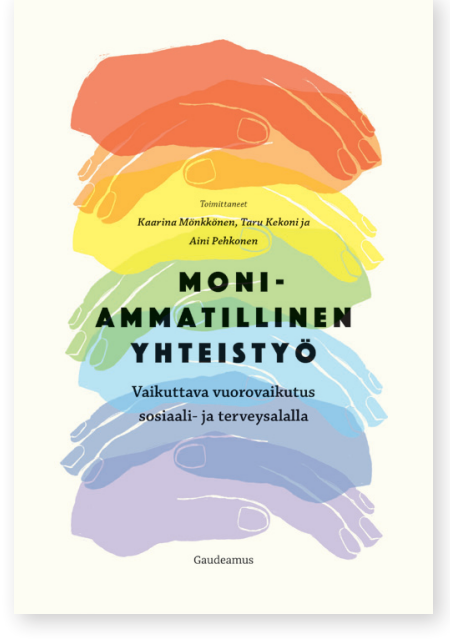

Erilaisten työkulttuurien kohtaamisessa tarvitaan rohkeutta katsoa asioita uudesta näkökulmasta ja kyseenalaistaa aiempia oletuksia. Vuorovaikutuksessa on mahdollista hyödyntää toisten asiantuntemusta oman näkökulman laajentamiseksi, jos toimijat luottavat toisiinsa.

Kirjassa muun muassa esitellään tutkimusta, jossa lääkärit kuvaavat moniammatillisen toiminnan lisäarvoa omalle työlleen. Lääkärien mielestä yhteinen työ edellytti selkeitä rooleja ja vastuiden tekemistä näkyväksi. Esimerkkiin on helppo samastua, helpottavathan selkeät roolit ja vastuut vuorovaikutusta.

\section{KOULUTUKSELLA}

MONIAMMATILLISTA OSAAMISTA

Kirjassa tuodaan esille palvelualojen integraatio, jossa moniammatillinen osaaminen korostuu. Yhdistämällä asiantuntijatietoa saadaan kokonaisvaltainen kuva asiakkaasta ja päädytään tämän 
SELKË̈T ROOLIT JA

VASTUUT HELPOTTAVAT

VUOROVAIKUTUSTA.

kannalta parhaaseen ratkaisuun. Moniammatillisen työskentelyn vaatimia taitoja onkin tärkeä harjoitella jo opiskeluvaiheessa, jotta eri alojen opiskelijat saavat kokemusta yhteisestä ongelmanratkaisusta.

Moniammatillisessa koulutuksessa tuotetaan ryhmä- ja yhteistyötaitoisia ammattilaisia. Lisäksi vaikutetaan asenteisiin ja käsityksiin eri ammattialojen työtavoista, työmenetelmistä ja työn lähtökohdista. Maailman terveysjärjestö WHO esimerkiksi korostaa terveydenhuollon kokonaisvaltaista, monitieteistä koulutusta ja pitää moniammatillista koulutusta edellytyksenä yhteistyökykyisten ammattilaisten rekrytoinnissa terveydenhuoltoon.

Eri ammattiryhmien yhteiset koulutukset lisäävät tietoa muiden ammattilaisten rooleista, mutta niitä voisi tarjota nykyistä enemmänkin. Moniammatillisen ja monitieteisen opintojakson järjestämisessä vaaditaan kärsivällisyyttä ja suunnittelua, sillä eri koulutusohjelmien ja oppiaineiden hallinto, toimintatavat tai taloudelliset resurssit voivat poiketa toisistaan ja hankaloittaa toteutusta. Yhteiset opintokokonaisuudet kuitenkin tuovat paljon oppimismahdollisuuksia - niin opiskelijoille kuin opettajille, jotka voivat tehdä jotain toisin kuin aiemmin.
LÄHDELUETTELO JOHDATTAA TIEDEARTIKKELIEN PARIIN

Kirja sisältää uutta tietoa ja käytännön esimerkkejä moniammatillisuudesta ja sen vaativan osaamisen kehittämisestä. Omat opetuskokemukseni saivat lukiessa vahvistusta, ja esimerkit innostivat toteuttamaan uusia avauksia omassa työssä. Kirjallisuutta aihepiiristä etsiville teos on kulta- kaivos, sillä monipuolinen lähdeluettelo johdattaa kiinnostavien tiedeartikkelien pariin.

On turvallista toimia vain oman alan asiantuntijoiden parissa, mutta moniammatillinen työ voi tuoda työhön lisäarvoa.

\section{SANNA JUVONEN}

KM, kehityspäällikkö, Laurea-ammattikorkeakoulu

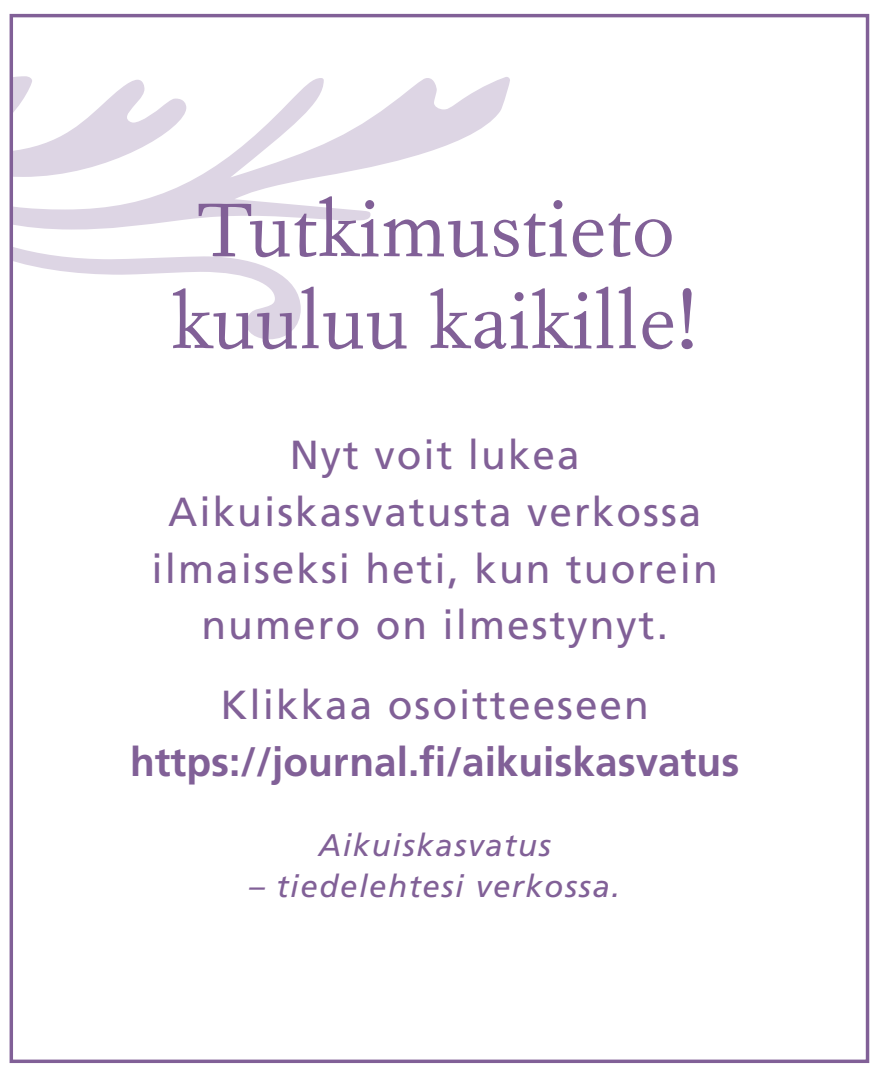

